\title{
Philosophical and socio-psychological meaning of the concept of psycho violence in learning environment
}

\author{
Alfiya R. Masalimova - Badma V. Sangadzhiev - Rozalina V. Shagieva - \\ Ramin A. Gurbanov - Sergey P. Zhdanov
}

DOI: 10.18355/XL.2018.11.01.12

\begin{abstract}
Currently one of the hot topics that have become a challenge for profound philosophical and socio-psychological investigation is a is psycho violence threat to learning environment safety and psychological safety, as its major component. The article concentrates on revealing the factors of psycho violence in the learning environment from the points of view of social philosophy and social psychology. Methodological framework of the studies is based on philosophical principles of dialectic synthesis, the transformation of quantity into quality, the unity and conflict of opposites, the principles of contradiction and determinism, and social psychology activity-system approach. These principles allowed the authors to consider the level of 'psycho violence' development and identify the main approaches and determinants of its dissemination in education and learning environment. The paper discusses the definition of the term 'psycho violence', as well as presents theoretically justified factors influencing a propensity for psycho- violence which involve direct and indirect verbal aggression, indirect physical aggression, low communicative tolerance, the tendency to dominate and manipulate, selfishness, craving power over other people, a negative attitude towards others, disregard for the community norms and regulations, rigidity, anxiety, and extraversion. All of them are considered as objectives when developing the work to prevent psycho- violence. Hence, the materials of the article are of practical value for specialists engaged in designing psychological and educational programs aimed at prevention of psycho- violence in the learning environment.
\end{abstract}

Key words: psycho-violence, learning environment, philosophical treatment, sociopsychological understanding, personality traits

\section{Introduction}

At the present stage of Russian education development the challenge of providing students nationwide with a safe environment, an integrated security system, which is able to keep students, parents and employees well informed about their learning environment security have come to the fore. Provision of psychological security aspects that affect the learning process is one of the integrated security system elements and involves introducing preventive measures and measures to minimize the negative consequences of interpersonal communication, psychological manipulation, psychological violence, emotional abuse and psycho violence.

Modern psychological science studies forms of psychological violence and emotional abuse, psycho violence and its impact on mental, emotional, will and value-based, motivational and other spheres specific to personality considered as an object of psycho- violence (Volkov, 2002; Ilyin, 2013; Lapteva, 2010; Tsymbal, 2007; Kirillova et al., 2017; Shcherbakov et al., 2017). Little attention has been paid to the study of philosophical and socio-psychological analysis of psycho-violence as a phenomenon, its scientific interpretations, as well as factors contributing to the propensity for psycho violence. On the basis of a theoretical study of research carried out on psychological abuse, violence and related areas (Baeva, Volkov, Laktionova, 
2003; Zinovieva, Mikhailova, 2003; Sokolova, 2013; Ilyin, 2014) we have identified the key factors referring to the propensity of a person for psycho violence.

The study of violence and aggression relationship led to a conclusion that propensity of a person for psycho violence may be determined by the person's propensity toward verbal aggression, both direct and indirect (behavior when one's own negative emotions are expressed by intonation or other nonverbal components of speech, as well as by the content), and a tendency to use indirect physical aggression (aggressive feelings against any person or item are hidden or are not recognized by the actor of aggression, an indirect use of physical force is also possible).

There is an evident dependency of the propensity of a person for psycho violence on his propensity to manipulate other people. Manipulation is a type of social influence that aims to change the behavior or perception of others through abusive, deceptive, or underhanded tactics that do not coincide with his actual existing desires and wills (Ilyin, 2014). This is hidden control of the recipient by the initiator, in which the latter achieves its goals to the detriment of the recipient (Sheinov, 2010).

There is an obvious tendency to consider the propensity to dominate as one of the factors of the propensity for psycho violence. This trait is often looked upon as desire to occupy a priority position in the hierarchy of social relations; it involves the struggle to achieve the aim. It is characterized by a desire to control the person's own social environment, to influence others, advise, seduce, convince, command, forbid and dissuade (Ilyin, 2014).

A strong need to attain feelings of power and superiority, control and management in relationships with others in all the processes taking place around the person is also determined as the basic feature of psycho-violence.

Other factors distinguished are a selfish orientation of the personality, negative attitude towards others, propensity for violating values, moral norms, and society regulations, and communicative intolerance. As for individual psychological characteristics, they mostly involve rigidity, anxiety, and extroversion.

\section{Methodological Framework}

In this study, we draw from the philosophical principles of dialectic synthesis, the transformation of quantity into quality, the unity and conflict of opposites, and the principle of dialectical contradictions.

\section{Philosophical principles}

In our study, we relied on the principle of determinism which states that for every event there exist conditions that could cause no other event. Determinism includes aetiology with the following features:

1) the relations of cause and effect, when cause creates the effect and never vice versa;

2) temporal asymmetry: the cause always precedes the effect and not the other way round;

3) the need - regardless of location in space and time the result necessarily comes: equal causes always produce an equal result;

4) spatial and temporal continuity - cause and effect constitute a chain of events in time and space regardless of their spatial and temporal location (Alekseev, Panin, 2003).

\section{Theoretical approaches}

A leading approach to study this problem is activity system approach. In this approach, the activity is considered as one of the active human existences which are primarily focused on creative transformation and cognition of environment and life. Human cognition, as well as his psyche, are conceived and formed only in activities, and specifically in activities, they manifest themselves. In other words, psyche and 
activities are interrelated, and not isolated from each other. Activity has the following characteristics:

1. Activity as a system of human 'doing' develops throughout the human's life and socialization (education and training).

2. Carrying out any activity, a person is able to go beyond the limits of his consciousness, create spiritual and material values which in turn contribute to historical development and progress of society.

3. Activity meets the needs of a person: natural, cultural, cognitive, etc.

4. It is productive, i.e., participation in activities helps to constantly create new ways to meet one's needs (Rubinstein, 2012).

\section{Results}

To understand the essence of psycho-violence we have conducted a study of different approaches to understand and interpret the concept of violence as a general category.

Social and philosophical nature of violence and features, links and relationships formed have been discussed in the works of V.E. Petrishcheva (1998), Yu.M. Antonyan (2005), M. Sageman (2008), etc.

An attempt to distinguish the concept of 'terrorism' from other concepts to denote acts of violence were made by G.K. Vardanyants, (2005), P. Krusanov (2004), I.F. Luppov (2009), etc.

Increase in the globalization of social and political life has made the problem of deviations emergence in human behavior and outlook more urgent. The development of violence in this context was discussed in the works of various authors, including A.A. Guseynov (1994), Yu. Ivanic (2005), Y.V. Latova (2007), V.R. Soloviev (2011), and others. The study of their works shows that modern violence has qualitatively changed in connection with globalization development which, on the other hand, opens up opportunities for the global struggle against violence involving international political organizations, military structures, and mass media.

The works of V.N. Kudryavtseva (2003), K. Hirschman (2002), and A.S. Gratchev (2007), and some other authors presented an analysis of the nature, types, and specifics of terrorist activities in the global world. Terrorist acts are regarded as a distorted form of social condition determination being affected by social actions of the destructive character, mobilizing a variety of resources that are able to influence the quality of social transformations, their deviation from the existing institutional traditions significantly (Maslova, 2003).

It is impossible to create protection mechanisms against terrorist attacks without having studied its nature. In order to effectively counter violence and predict it, it is necessary to identify and analyze their root causes. The study of the causes of violence represented in the works of Ye.G. Lyakhova, A.B. Popov (1999), S.A. Arutyunov (2004), and M.K. Asanbekov (2005) highlighted the need for a balanced approach, making a careful, thorough, systematic analysis of the causes of terrorist activity.

Ideological foundation for the phenomenon of violence has been discussed by Russian researchers J.K. Toshchenko (2003). N. Afanasyev (2001), M.M. Reshetnikov (2005), and E.P. Kozhushko (2000).

Psychological traits of violence determined in their works by E. Fromm (2017), D.V. Olshansky (2002), and V.R. Soloviev (2011) proved that the degree of violence of terrorist actions is largely mediated not only by ideological, doctrinal, peculiarities and causes but also psychological traits, and they all are closely interrelated.

Investigations carried out by P. A. Sorokin (1992), I.K. Dzherelievskaya (2005), Yu. Habermas (1995) are of great significance when properly considering the role of social and cultural factors in violence. These authors suggested that countering violence requires not only a change in the mode, standards, and conditions of people's 
lives, but also depend on the implementation of appropriate social and cultural public policy.

The study has proved that contemporary violence is a global phenomenon. It is caused by social and cultural integration and social and economic inequality, development of information technologies and the resulting conflicts between states, societies, and individuals, as well as ethnic and confessional contradictions. Terrorist activity in the modern world might be caused by negative consequences of globalization, the activity of some social groups or national entities, and recently, individuals; it seeks to change the perceived as an unfair and not acceptable form of the public order. Terrorist activity constitutes a new form of war focused on the asymmetric actions helping to those who, though technologically and organizationally inferior, acquire the means and ability to conduct short-term or long-term terrorist actions. Violence has its philosophical, ideological and psychological reasons. They are determined by philosophical, ideological, doctrinal, and psychological views. It is philosophical and ideological differences that have a significant impact on the psychology of a terrorist (Malyshev, 2011).

Now consider the concept 'psycho violence'. It is a relatively new concept in psychology, and there is not such high research carried out on this subject in Russia. Social psychologists are paying attention mostly to study the effect of different terrorist events, technological disasters on the human psyche, and psychological peculiarities of a terrorist's personality. There is a tendency to merge the concepts of psycho-violence and social terrorism. Thus, D.V. Olshansky (2002) suggests that psycho violence is closely connected to a social situation that holds all members of society or a particular group in fear and constant tension. But such a consideration overlooks that in contrast to conventional terrorism in the case of psycho- violence we discuss the moral-and-psychological direct influence of one person on another (most often expressed verbally) (Cheverikina, Gryaznov, Sharafiev, 2016).

As in modern psychological science, there is no accepted conventional definition for psycho-violence, then taking into account different case studies of psychological and pedagogical practice might be rewarding. We define 'psycho violence' as impact of one actor on another, in which the impacted actor by means of negative psychological techniques (intimidation, humiliation, ignoring, etc.) consciously or unconsciously tries to improve his social value, his self-attitude and attitude towards him of the people surrounding him (I'm strong; I'm independent; I'm the coolest; I can do anything; Those who do not join me, or are not like me, are insignificant and not worthy of my good attitude to them), and the other actor influenced feels powerful emotional discomfort causing him psychological injuries of various types and severity. Based on social and psychological investigation outcomes we can conclude that psychological manipulation and psychological abuse basically have a clear goal set to provoke the recipient's (actor under the influence) actions on the cognitive or behavioral level (i.e., to think of or to perform actions) and make him do what is desirable to the initiator (the actor influencing) that triggered the event. With psycho terroristic event, which is the two-sided coin because the basic behavioral impact for one of the sides, participants, is associated with humiliation, harassment, creation of emotional discomfort; therefore, for another side, participant, the psycho violence event becomes a way of imposing desired thoughts and actions, a way of experiencing pleasure from committing the psycho terroristic action, enhancing his self-esteem and importance of him in the eyes of the immediate environment. In learning, or educational, environment psycho violence might occur in relations of the following participants: a student vs. a student, a group of students vs. a student, a students' group vs. a students' group, a teacher vs. a student, a teacher vs. a class, a teacher vs. a teacher, a teacher vs. a group of teachers, a group of teachers vs. a group of teachers.

XLinguae, Volume 11 Issue 1, January 2018, ISSN 1337-8384, eISSN 2453-711X 
Moreover, each of participants in the interaction may be both the terror subject and the opponent of the psycho violence event impact (Cheverikin, Fatina, 2017).

\section{Discussions}

Conducting a literature review in this paper, we wanted to show that there are different definitions for concepts of psychological manipulation, psychological abuse, and psycho-violence which often overlap and do not give a clear and precise description for the essence of the facts that are referred by them to social-andpsychological phenomena.

Among the terms and concepts analyzed the term 'psychological manipulation' has the most extensional definition. Russian psychology researchers attempted to study the main social-and-psychological definitions given for the concept, highlighted the main criteria and on this basis define their own understanding of 'psychological manipulation' term. Thus, after having studied the works of domestic and foreign scientists, E.L. Dotsenko (1997) identified a number of criteria which were applied by the authors to define 'psychological manipulation.' He noticed that the criterion established for it by most of the authors is associated with some action characterized as 'hidden, deceptive, underhanded.' The second top criterion is associated with 'exploitation and domination.' It is followed by features describing the behavior as 'management and control,' enforcement,' "use the victim as a thing,' 'indirect impact, influence' and 'programming ideas, intentions, etc.' Other characteristics enlist 'structuring the world', 'the interests of the manipulator', 'at odds with the will of the other', 'provocation', 'exploiting victim's weakness', 'a non-violent way', 'spiritual impact', 'focus on the spiritual state and inner peace', etc. (Dotsenko, 1997). He put all the criteria together and divided them into five feature groups, for each he distinguished a generalized criterion that could enter into the final definition of 'manipulation' term: 1) generic indicator - psychological impacts; 2) treating a manipulator to another person as a means of achieving his goal; 3) the desire to obtain one-sided benefit; 4) the hidden nature of the impact (of exposure and its focus); 5) the use of (psychological) forces, play on people's vulnerabilities. The author also noted that two criteria appeared to be somewhat detached: 'motivation, motivated introduction' and 'the art and skill in pursuing manipulative actions' (Dotsenko, 1997).

On the basis of the features selected, E.L. Dotsenko (1997) formulated the following definition of manipulation: manipulation is a type of psychological influence, proper execution of which leads to the hidden stimulation of the other person's intentions that in fact did not coincide with his actually existing wills.

Performing a similar analysis, V.P. Sheinov (2010) conducted a survey on the same subject for more than twenty authors, allocated the definitions of psychological manipulation given by these authors and divided them taking into account three types of concepts:

1. Almost all definitions consider manipulation as a specific method to control the person being manipulated.

2. Most definitions directly point to the hidden nature of the impact.

3. Many definitions emphasize that advancing the interests of the manipulator, often at another's expense, is condemnable and causes damage to the other person's psyche and/or emotional wellbeing. Moreover, only the initiator of the manipulation is to benefit, and the manipulated person is considered as a victim under hidden control (Sheinov, 2010). The study conducted allowed the author to give the following definition of 'manipulation' which, in his opinion, involves the most significant of all known features of this concept: manipulation is a hidden control of the recipient by the initiator where the latter achieves his goals but is detrimental to the recipient (Sheinov, 2010). He lays emphasis on the fact that psychological manipulation is 
always associated with damage to the recipient, the victim. In our opinion, this significantly narrows interpretation of the concept of psychological manipulation as it is not necessarily negative, and it may involve positive reinforcement for the benefit of the person manipulated, for example, in the process of psychotherapy (doctors can try to persuade patients to change unhealthy habits), in learning process, and, in education.

E. A. Shcheglova (2010) wrote that psychological manipulation is an important element of pedagogical activity, may be conscious or unconscious, and when discussing it, it is important to recognize the aim of manipulation, if it is for the person's benefit (manipulated) or for the benefit of the manipulator. She gives her definition for a' propensity for manipulation' related to vocational and educational realities: the tendency of teachers to manipulate is a personal construct existing in the form of psychological readiness to actualize students ' intentions that do not coincide with their actual existing wills and desires, needs and motives; manifested in the form of impacts on students that may correspond to pedagogical interventions (in the framework of pedagogical interactions) or go beyond them, in some cases completely replacing them (Machiavellianism) (Shcheglova, 2009). In the first case, manipulation implies a positive impact when manipulative techniques are used only in certain situations and are aimed at achieving socially desirable objectives, e.g., learning performance improvement, correction of undesirable behavior, etc.

The criterion 'harm to the recipient' probably refers to psychological manipulation associated with 'psychological violence.' For that purpose, we have considered the definition of 'psychological violence,' a concept used in contemporary social and psychological science.

A.A. Guseinov $(1994,2006)$ when defining violence wrote that it is external, force impact on the person or group of people in order to subject them to the will of the one who performs the action. At the same time, A.Y. Yegorov and O.G. Freidman (2003) distinguished violence as a physical, social-and-organizational, mental (verbal or moral) influence on a person that wrongfully lowers his moral (spiritual), social (including legal) and vital status, causes him physical and mental suffering, or it might be a threat of such exposure.

The definition of 'psychological violence' given by A.B. Orlov (2000) considers this phenomenon from the perspective of the parent-child relationship. He defined psychological violence as adults' deliberate manipulation of children as objects, ignoring subjective characteristics (freedom, dignity, rights, etc.), destructing attachment relations between an adult and a child, or, conversely, fixing them and resulting in different deformations and disorders of psychological development.

A.Y. Yegorov, O.G. Freidman (2003) carried out theoretical analysis of the problem which allowed them to assume that 'psychological abuse' is an impact on self-concept of a person which is able to change it negatively and result in disorders in the development of his individual personal qualities, emotional and intellectual development, adaptation in society, and mental diseases. Authoritarian and manipulative methods of influence might be considered as psychological violence, as their purpose is to explicitly or implicitly subordinate another person to one's own purpose and effect.

Thus, by analyzing different approaches we can conclude what psychological violence is a social and psychological impact forcing other people to act, behave and do things they were not intended to; violation of personal boundaries conducted without informing them, involuntarily and without providing social and psychological safety measures and ensuring all legal rights; and in the long run resulting in social, psychological, physical or material harm.

Psychological abuse is a form of abuse characterized by a person subjecting, or exposing, another person to behavior that may result in psychological trauma and is

XLinguae, Volume 11 Issue 1, January 2018, ISSN 1337-8384, eISSN 2453-711X 
associated verbal abuse, blackmail, threats of physical violence, bullying, control over victim's activities, control over his access to various resources, harassment, etc.

E.N. Volkov (2002) made a survey of the ideas expressed by quite a big number of foreign authors that have studied 'psychological violence' since the beginning of the 20th century. He identified the following features that characterize "psychological violence': mental struggle; brainwashing; reform of consciousness; a syndrome of weakness, dependence and fear; coercive persuasion, zombies, control of consciousness, coercive influence, behavioral control and mind control; and exploiting persuasion. He defined 'psychological violence' as social and psychological impact deliberately coercing another person or a group of people to actions or behaviour that were not part of their intentions; violation of psychological boundaries of the individual or social group carried out without informing them and without ensuring their social and psychological safety and security, as well as all of their legal rights; and leading to social, psychological, physical or material harm.

\section{Conclusion}

The research carried out allowed us to draw a conclusion that understanding and distinguishing psycho violence might be derived from the intersection of the concepts of violence (violence activity), and manipulation.

Psycho violence is understood and interpreted as the influence of one person on another, interaction in which the person (as a subject) significantly interferes with an object being influenced using negative psychological methods and techniques (intimidation, humiliation, ignoring, etc.); consciously or unconsciously tries to improve his social importance for another person's (being influenced) expense, improve his self-attitudes, and attitude on the part of the surrounding community (I am strong, I am independent, I am tough and cool, I can do everything, Those who are not with me or not like me are worthless and do not deserve to be treated well). The object of influence feels a strong emotional discomfort that will result in his psychological injuries of various types and severity. Based on the foregoing, it can be concluded that psychological manipulation and psychological violence have a clear and specific goal - to make the recipient (object of influence) operate at the cognitive or behavioral level (to think or to do things) as desired by the initiator (the subject of the exposure). In psycho violence humiliation, harassment, creation of emotional discomfort become the basic behavioral acts of the subject-object relations, that is possible to say that psycho violence becomes not so much a way of imposing the object of impact the desired ideas, thoughts and actions, but a way of having pleasure from psycho terroristic actions performed, improve the terrorist's self-esteem and importance in the eyes of entourage. In educational environments, psycho violence may occur between the following participants in the learning process: a student - a student, a group of students - a student, a group of students- a group of students, a teacher - a student, a teacher - a class, a teacher - a teacher, a teacher - a group of teachers, a group of teachers - a group of teachers. Each of participants of interaction in the learning environment can be both a subject and an object psycho violence impact.

The materials of this article may be used by teachers of philosophy and social psychology; it might be of practical importance for experts working on developing a program to prevent psycho- violence, psychological violence, and manipulation; for understanding not only instruments but also more profound reasons of their formation. In the course of the research new issues have arisen. Therefore, we are going to continue it so as philosophical understanding of psycho-violence is significant. Psycho violence has become a threat not only to the psychological security of the learning environment but for society and the world community as well. 


\section{Acknowledgement}

1. The work is performed according to the Russian Government Program of Competitive Growth of Kazan Federal University.

2. The work was carried out with the support of the Ministry of Education and Science of the Russian Federation under the Peoples' Friendship University of Russia (RUDN University) Program "5-100" among the world's leading research and educational centers for 2016-2020.

\section{Bibliographic references}

AFANASYEV, N.N. 2001. The ideology of terrorism. In: Socio-humanitarian knowledge, n. 6, pp. 205-219. ISSN: 0869-8120.

ALEKSEEV, P.V. - PANIN, A.V. 2003. Philosophy. Moscow: TK Velbi, Prospect publishing house. ISBN 5-98032-164-0.

ANTONYAN, Yu.M. 2005. Suiciding terrorism. In: Bulletin of the Russian Academy of Sciences, vol. 75, n. 9, pp. 818-824. ISSN 0869-5873.

ARUTYUNOV, S.A. 2004. Terrorism and civilization: the serpent biting its own tail. In: Foreign literature, n. 9, pp. 226-233. ISSN 0130-6545.

ASANBEKOV, M.K. 2005. International terrorism in Central Asian countries. In: Sociological researches, n. 9, pp. 126-130. ISSN 0132-1625.

BAEVA, I.A. - VOLKOV, E.N. - LAKTIONOVA, E.B. 2011. Psychological safety of the educational environment of personality development. Saint Petersburg: IZDATELSTVO. ISBN 978-5-98187-638-7.

CHEVERIKINA, Ye.A. - FATINA, M.L. 2017. Psychological manipulation, psychological abuse, psychoterrorism in the educational environment: the issue of definition of concepts. In: The matrix of scientific knowledge, n. 1-2, pp. 89-101. ISSN 2541-8084.

CHEVERIKINA, Ye.A. - GRYAZNOV, A.N. - SHARAFIEV, E.S. 2016. Of its convenient Individual psychoterrorism in interpersonal communication of teenagers. In: Kazan pedagogical journal, vol. 3, n. 116, pp. 145-150. ISSN 1726-846X.

DOTSENKO, Ye.L. 1997. Psychology of manipulation: phenomena, mechanisms and protection. Moscow: MGU publ. ISBN: 5-88711-038-4.

DZHERELIEVSKAYA, I.K. 2005. Socio-cultural policies in the mirror of the fight against terrorism. In: Socio-humanitarian knowledge, n. 6, pp.108-125. ISSN: 08698120.

FROMM, E. 2017. Anatomy of human destructiveness. Moscow: AST. ISBN: 978-517-103239-5.

GRATCHEV, S.I. 2007. Terrorism. Issues of theory. Nizhny Novgorod: Publishing house of the Nizhny Novgorod University. ISBN 978-5-91326-001-7.

GUSEINOV, A.A. 2006. Morality and violence the Concept of violence. Ethics: a Textbook for philosophical faculties. Moscow: Gardariki. ISBN: 5-8297-0030-1.

GUSEINOV, A.A. 1994. The concepts of violence and nonviolence. In: Problems of philosophy, n. 6, pp. 43-52. ISSN: 0042-8744.

HABERMAS, Yu. 1995. Democracy. Mind. Morality. Moscow: Academia. ISBN: 5861870446.

HIRSHMAN, K.M. 2002. The changing guise of terrorism. In: Social Sciences and Humanities. Domestic and foreign literature, n. 4, pp. 26 -36. ISSN: 2219-861X.

ILYIN, Ye.P. 2014. The Psychology of aggressive behavior. Saint Petersburg: Peter. ISBN 978-5-496-00991-1.

ILYIN, Ye.P. 2013. Violence as a psychological phenomenon. Universum: In: Vestnik of the Herzen University, n. 1, pp.167-174. ISSN 2306-9880.

IVANIC, Yu. 2005. Drugs and terrorism: in the spider's web. Moscow: Veche. ISBN 5-9533-0521-4.

XLinguae, Volume 11 Issue 1, January 2018, ISSN 1337-8384, eISSN 2453-711X 
KIRILLOVA, E.A. - KURBANOV, R.A. - SVECHNIKOVA, N.V. ZUL'FUGARZADE, T.E. - ZENIN, S.S. 2017. Problems of Fighting Crimes on the Internet. In: Journal of Advanced Research in Law and Economics, vol. 8, n. 3, pp. 849-856. ISSN: 2068-696X

KOZHUSHKO, Ye.P. 2000. Modern terrorism: an analysis of the main directions. Minsk: Kharvest. ISBN 985-433-723-5.

KRUSANOV, P. 2004. The current model of hell: essays on the terrorism and the terrorists Moscow: AST. ISBN 5-17-027321-5.

KUDRYAVTSEVA, V.N. 2003. The strategy of the fight against crime. Moscow: Jurist. ISBN: 978-5-91768-704-9.

LAPTEVA, V.Yu. 2010. Psychological characteristics of adolescents with different levels of protection from psychological violence in the educational environment. $\mathrm{PhD}$ Thesis. Saint Petersburg: Russian state pedagogical University. A. I. Herzen.

LATOVA, Yu.V. 2007). Economic analysis of terrorism. In: Social Sciences and modernity, n. 5, pp. 28-45. ISBN: 465-7-432-76307-6.

LUPPOV, I.F. 2009. The sources of modern terrorism: main conceptual approaches. In: Bulletin of Bashkir state University, vol. 14, n. 2, pp. 628-631. ISSN 1998-4812.

LYAKHOVA, Ye.G. - POPOV, A.B. 1999. Terrorism: national, regional and international control. Rostov-on-Don: Rostov Law Institute of the Ministry of internal Affairs of Russia. ISBN: 5-89288-048-6.

MALYSHEV, Ye.N. 2011. the Phenomenon of modern terrorism: socio-philosophical analysis. PhD Thesis. Krasnoyarsk: Siberian state University.

MASLOVA, O.V. 2003. The state of society and forms of their activity determination (Socio-philosophical analysis). PhD Thesis. Krasnoyarsk: Siberian state aerospace University.

OLSHANSKY, D.V. 2002. Psychology of terrorism. Saint Petersburg: Piter. ISBN 59552-0201-3.

ORLOV, A.B. 2000. Psychological violence in the family definition; aspects, main directions of psychological assistance. In: Psychologist in kindergarten, n. 2-3, pp. 182-187.

PETRISHCHEVA, Ye.V. 1998. Legal and socio-political problems of the fight against terrorism. In: The state and law, n. 3, pp. 88-93pp. ISSN: 0132-0769.

RESHETNIKOV, M.M. 2005. Youth activism and terrorism. In: The basics of life safety, n. 9, pp. 44-49. ISSN 1998-0736.

RUBINSTEIN, S.L. 2012. Man and the world. Saint Petersburg: Piter. ISBN 978-5459-00888-3.

SAGEMAN, M. 2008. The network structure of terrorism. Moscow: Idea-Press. ISBN: 978-5-903927-04-3

SHCHEGLOVA, E.A. 2009. Propensity for manipulation and forms of its manifestation in professional pedagogical activities. PhD Thesis. Tomsk: Tomsk state University.

SHCHERBAKOV, V.S. - ASHMARINA, S.I. - SURAEVA, M.O. - KURBANOV, R.A. - BELYALOVA, A.M. - GURBANOV, R.A. - TORKUNOVA, J.V. 2017. Iteration as a Regulatory Function of Education Management. In: Eurasian Journal of Analytical Chemistry, vol. 12, n. 7, pp. 1211-1219. e-ISSN: 1306-3057

SHEINOV, V.P. 2010. The Manipulation of consciousness. Minsk: Kharvest. ISBN 978-985-16-6930-7.

SOKOLOVA, N.N. 2013. Violence. General psychological performance. http://www.b17.ru/article/13010/.

SOLOVIEV, V.R. 2011. The Enemies Of Russia. Moscow: Eksmo. ISBN 978-5-69952340-5.

SOROKIN, P.A. 1992. People. Civilization. Society. Moscow: Publishing house of political literature. ISBN: 5-250-01297-3. 
TOSHCHENKO, Zh.T. 2003. Ethnocracy: history and modernity (sociological essays). Moscow: ROSSPEN. ISBN 5-8243-0395-9.

TSYMBAL, Ye.I. 2007. maltreatment of children: the causes, manifestations, consequences. Moscow: Russian charity Foundation "No to alcoholism and drug addiction", 166 pp. Available online: http://rudocs.exdat.com/docs/index-202134.html VARDANYANTS, G.K. 2005. Terrorism: diagnosis and social control. In: Sociological researches, n. 7, pp.78-83. ISSN 0132-1625.

VOLKOV, E.N. 2002. Criteria, characteristics, definition and classification of harmful psychological effects: psychological injury, psychological aggression and psychological abuse. In: Journal of the practicing psychologist, n. 6, pp. 183-199. ISSN 5-89395-089-5.

YEGOROV, A.Yu. - FREIDMAN, O.G. 2003. Psychological abuse and personal development. - Saint Petersburg: Russian charitable Foundation "No to alcoholism and drug addiction", 68 pp. Available online: http://nan.ru/?d=document/5region \&f=document/index

ZINOVIEVA, N.O. - MIKHAILOVA, N.F. 2003. Psychology and psychotherapy of violence. A child in a crisis situation. St. Petersburg: Speech. ISBN 5-9268-0186-9.

Words: 5038

Characters: 35174 (19,54 standard pages)

Prof. Alfiya R. Masalimova, Dr.

Institute of Psychology and Education, Kazan (Volga region) Federal University

18 Kremlyovskaya Str., 420008 Kazan

Russia

alfkazan@mail.ru

Prof. Badma V. Sangadzhiev, Dr.

Department of Judiciary, Law-Enforcement and Human Rights Activity

RUDN University (Peoples' Friendship University of Russia)

6 Miklukho-Malkaya Str., 117198, Moscow

Russia

lotos-75@mail.ru

Prof. Rozalina V. Shagieva, Dr.

Department of State and Legal Disciplines of the Institute of Public Administration and Management,

The Russian Presidential Academy of National Economy and Public Administration, 82 Prospect Vernadskogo Str., Building 1, 19571, Moscow

Russia

rozalina.shagieva@mail.ru

Prof. Ramin A. Gurbanov, Dr.

Department of Civil Legal Disciplines, Plekhanov Russian University of Economics

36 Stremyannyi Pereulok Str., 115093 Moscow

Russia

ramingurbanov@yahoo.com

Assoc. Prof. Sergey P. Zhdanov, PhD

Department of Criminal Law, Disciplines of the Faculty of Law

Russian Customs Academy

4 Komsomolskiy Prospect, 140015, Lyubertsy, Russia

zhdanov120009@yandex.ru

XLinguae, Volume 11 Issue 1, January 2018, ISSN 1337-8384, eISSN 2453-711X 